\title{
Occurrence of Sturnira tildae De La Torre, 1959 (Chiroptera: Phyllostomidae) in the state of Maranhão, Brazil
}

\author{
Amanda Cristiny da Silva Lima ${ }^{1,5}$; Cleison Luís da Silva Costa ${ }^{2,6}$; Samira Brito Mendes ${ }^{3,7}$; Fabio Henrique Souza Cardoso ${ }^{1,8}$; \\ Bruno Augusto Torres Parahyba Campos ${ }^{2,9}$; Elmary Costa Fraga ${ }^{4,10}$ \& Maria Claudene Barros ${ }^{4,11}$
}

1 Universidade Estadual do Maranhão (UEMA), Programa de Pós-Graduação em Ciência Animal. São Luís, MA, Brasil.

${ }^{2}$ Universidade Estadual do Maranhão (UEMA), Centro de Estudos Superiores de Caxias (CESC), Programa de Pós-Graduação em Biodiversidade Meio Ambiente e Saúde. Caxias, MA, Brasil.

3 Universidade Estadual do Maranhão (UEMA), Programa de Pós-Graduação da Rede de Biodiversidade e Biotecnologia da Amazônia Legal BIONORTE. São Luís, MA, Brasil.

${ }^{4}$ Universidade Estadual do Maranhão (UEMA), Centro de Estudos Superiores de Caxias (CESC), Departamento de Química e Biologia (DQB), Laboratório de Genética e Biologia Molecular. Caxias, MA, Brasil.

${ }^{5}$ ORCID: http://orcid.org/0000-0001-6202-8058.E-mail: amanda01cristiny@outlook.com

${ }^{6}$ ORCID: http://orcid.org/0000-0003-1717-9994.E-mail: cleison-costa@outlook.com

7 ORCID: http://orcid.org/0000-0003-0291-6859. E-mail: mendesbrito25@gmail.com

${ }^{8}$ ORCID: http://orcid.org/0000-0001-6446-1031.E-mail: fabiohenrique16s@hotmail.com

${ }^{9}$ ORCID: http://orcid.org/0000-0001-5586-2597. E-mail: atpcampos@gmail.com

${ }^{10}$ ORCID: http://orcid.org/0000-0001-8062-0338. E-mail: elmaryfraga@yahoo.com.br

${ }^{11}$ ORCID: http://orcid.org/0000-0001-9055-1911. E-mail: mbdene@yahoo.com.br (corresponding author)

\begin{abstract}
The bat genus Sturnira is widely distributed in the Neotropical region, from northwestern Mexico to northern Argentina, and four species occur in Brazil: Sturnira lilium, Sturnira giannae, Sturnira magna, and Sturnira tildae. The present study is the first to record Sturnira tildae in the state of Maranhão, Brazil, based on morphological and molecular diagnoses. The specimen was identified based on its cranial and morphometric traits. The diagnostic traits include discreetly bilobed inner upper incisors with a broad base, lower first and second molars with lingual cusps separated by shallow grooves, and forearm longer than $45 \mathrm{~mm}$. The molecular sequences of Cytochrome C Oxidase Subunit 1 (COI) and 16S rRNA genes confirmed the morphological identification and thus the occurrence of Sturnira tildae in the Amazon biome of Maranhão. This record represents an eastward extension of the known distribution of the species in the Amazonia, to Cândido Mendes, Maranhão, within an area dominated by dense rainforest and influenced by tides.
\end{abstract}

Keywords. 16S rRNA; Amazon; COI; DNA barcode; Range extension; Stenodermatinae.

\section{INTRODUCTION}

Brazil has is the country with the third richest bat fauna in the world, with 181 species (including eight endemics) representing 68 genera and nine families (Garbino et al., 2020; Velazco 2021). Much of this diversity is found in the Amazon biome, which is home to most of the species known to occur in Brazil (Bernard et al., 2011). In this scenario, the Amazon of Maranhão, in the eastern extreme of the biome, is one of the Amazonian regions that have a fragmented distribution of bat species records, but which are gradually a number of recent studies have provided important insights into the distribution of chiropterans in this region (Bernard et al., 2011; Oliveira et al., 2011; Olímpio et al., 2016; Lima et al., 2018; Olímpio et al., 2018; Mendes et al., 2020).

Bats of the family Phyllostomidae are the most ecologically diverse group of mammals, and the second most speciose mammalian family, with 216 recognized species (Taylor \& Tuttle, 2019). In recent years, a number of studies reporting the fauna of poorly-known areas associated with phylogenetic analyses, have advanced the scientific understanding of phyllostomid diversity, including the discovery of new species and the expansion of the inventories available for many genera, such as Sturnira (Miretzki et al., 2002).

The phyllostomid genus Sturnira has a wide distribution in the Neotropical region, occurring from Mexico to northern Argentina (Gardner, 
2008). Sturnira is the most speciose phyllostomid genus, with 23 recognized species (Fleming et al., 2020), of which, four occur in Brazil - Sturnira lilium (Geoffroy, 1810), Sturnira giannae Velazco \& Patterson, 2019, Sturnira magna De La Torre, 1966 and Sturnira tildae De La Torre, 1959 (Garbino et al., 2020). Sturnira tilde is found in Brazil, Colombia, Ecuador, the Guianas, Peru, Bolivia, Trinidad and Tobago, and Venezuela (Simmons, 2005; Gardner, 2008). In Brazil, this species has been recorded in the states of Amapá, Amazonas, Pará, Acre, Tocantins, Ceará, Pernambuco, Bahia, Mato Grosso, Goiás, Mato Grosso do Sul, Espirito Santo, Rio de Janeiro, São Paulo, Paraná, and Santa Catarina (Martins et al., 2020).

Relatively few data are available on the diet or reproductive patterns of S. tildae, but this bat is assumed to be an important seed disperser, which contributes to the regeneration of forested areas (Simmons, 2005; Gardner, 2008). S. tildae shares a number of external characteristics with the other members of the genus, such as the lack of a tail, narrow and hairy interfemoral membrane, small ears, a small, broad nasal leaf, and posterior members and feet hairy, as far as the claws (Peracchi et al., 2011). The color of the pelage varies from tones of yellow to brown, with some males having tufts of orangish or dark reddish-brown hair on the shoulders (Reis et al., 2017).

The external measurements of S. tildae are similar to S. lilium, although S. lilium tends to be smaller (Gardner, 2008). Some studies point to the possibility of identification errors of identification related to the morphological similarities of these species and the overlap in their geographic distributions (Miretzki et al., 2002; Sampaio et al., 2016; Velazco \& Patterson, 2017; Martins et al., 2020). In areas that are in sympatry, S. lilium differs from S. tildae only by dental and morphometric characteristics (Simmons \& Voss, 1988; Martins et al., 2020). The present study uses morphological and molecular data to report on a new record of S. tildae from the state of Maranhão, which extends the known geographic distribution of the species in Brazil.

\section{MATERIAL AND METHODS}

Bats were collected in June 2016 in a fragment of forest located within the Amazon biome of the Brazilian state of Maranhão, in the municipality of Cândido Mendes. Specimen collection followed the procotol of Pacheco (2004) and permits were duly provided by the Brazilian federal agency for the environment (IBAMA/ SISBIO permit number 42670-3). The vegetation of the study region is dense rainforest typical of the Amazon biome, and it has a humid equatorial climate, as well as being influenced by the tides of the Maracaçumé River, which crosses the town of Cândido Mendes (Bandeira, 2013).

The specimen described here was collected using a $3 \mathrm{~m}$ high and $12 \mathrm{~m}$ long mist-net, with a $25 \mathrm{~mm}$ mesh. The age of the specimen was determined in the field based on the ossification of the phalangeal epiphyses, and its sex and reproductive status were also recorded (Brunet \& Austad, 2004). The specimen was photographed, euthanized, labeled, and stored on ice for transportation to the Genetics and Molecular Biology Laboratory (GENBIMOL) of Universidade Estadual do Maranhão (UEMA) in Caxias, Maranhão, where it was weighed and measured, and a sample of a muscle tissue was extracted, which was stored in ethanol $70^{\circ}$ for the molecular analyses.

The skull was extracted through the buccal aperture. Once clean, the skull was clarified with $10 \%$ peroxide and dried in a stove at $30^{\circ} \mathrm{C}$, after which, it was labeled and stored in a clean recipient. The specimen was fixed in formaldehyde and preserved in ethanol at UEMA's Laboratory of Genetics and Molecular Biology, on the campus of Caxias, and then transferred to the mammal collection of the Federal University of Paraíba, in João Pessoa, Brazil, where is it deposited. The specimen was identified based on its external traits and craniometric measurements, following Vizzoto \& Taddei (1973), Simmons \& Voss (1998), and Reis et al. (2013, 2017). Measurements taken include the length of right and left forearms, ear, tragus, foot, greatest length of the skull, basal length and condylobasal length, width of the brain case and the mastoid, zygomatic width, the length of the upper tooth row, and the width across the molars (Table 1). Body mass, after the specimen had been dead for hours, was determined using a precision balance after euthanasia of the specimen.

The total DNA was extracted from the muscle tissue using Promega's Wizard Genomic DNA Purification kit, following the default protocol. Two mitochondrial genes, Cytochrome C Oxidase Subunit 1 (COI) and rRNA 16S, were amplified by Polymerase Chain Reaction (PCR) using the primers LCO-1490 and HCO-2198 for the COI gene (Folmer et al., 1994) and L1987 and H2609 for the rRNA 16S (Palumbi et al., 2002). The samples were sequenced by the dideoxyterminal method of Sanger et al. (1977) in an ABI Prism ${ }^{\text {TM }} 3500$ (Applied Biosystems, USA) automatic DNA sequencer, using the Big Dye kit. The sequences were edited and aligned in BIOEDIT 7.0 (Hall, 1999), with the genetic divergence matrices being complied in MEGA X (Kumar et al., 2018) using the Kimura 2-parameter algorithm. The sequences were plotted in the BOLD Systems v4 (www.boldsystems.org) and BLAST (https://blast.ncbi.nlm.nih.gov/Blast.cgi) platforms to confirm their identification and determine their degree of similarity with sequences of other Sturnira species.

\section{RESULTS}

We collected an adult female $S$. tildae (field number: RRM 117, voucher: UFPB 11757) in June 2016 from a farm located within the urban perimeter of the town of Cândido Mendes $\left(01^{\circ} 27^{\prime} 21^{\prime \prime} \mathrm{S}, 45^{\circ} 43^{\prime} 32^{\prime \prime} \mathrm{W}\right)$, in the Amazon biome, within an area containing remnants of rainforest. The length of the right forearm was $45.77 \mathrm{~mm}$, while its left forearm was $46.34 \mathrm{~mm}$. The length of ear of the specimen was $12.95 \mathrm{~mm}$, the tragus $5.46 \mathrm{~mm}$, and the foot $12.45 \mathrm{~mm}$. The specimen was a non-lactating 
Table 1. Craniometric measurements (in $\mathrm{mm}$ ) of the Sturnira tildae specimen from Cândido Mendes, Maranhão, Brazil (present study), together with the values recorded from specimens of the same species from Recife (Pernambuco), Morretes (Paraná), and French Guiana.

\begin{tabular}{|c|c|c|c|c|c|}
\hline \multirow{3}{*}{ Measurements (mm) } & \multirow{3}{*}{$\begin{array}{c}\text { Present study } \\
\text { Cândido Mendes } \\
\text { Female }(n=1)\end{array}$} & \multirow{3}{*}{$\begin{array}{c}\text { Martins et al. (2020) } \\
\text { Recife } \\
\text { Female }(n=1)\end{array}$} & \multirow{3}{*}{$\begin{array}{c}\text { Miretzki et al. (2002) } \\
\text { Morretes } \\
\text { Male }(n=1)\end{array}$} & \multicolumn{2}{|c|}{ Simmons \& Voss (1998) } \\
\hline & & & & \multicolumn{2}{|c|}{ French Guiana } \\
\hline & & & & Female $(n=13)$ & Male $(n=11)$ \\
\hline Length of the skull & 23.6 & 23.6 & - & - & - \\
\hline Basal length & 18 & - & 18.5 & - & - \\
\hline Condylobasal length & 21.6 & 22.6 & 21.71 & 21.26 & 21.65 \\
\hline Length of upper tooth row & 7.1 & 7.6 & 7.10 & 6.87 & 6.81 \\
\hline Postorbital width & 6.2 & 6.5 & 6.55 & 6.16 & 6.21 \\
\hline Width of the mastoid & 11.9 & - & 12.92 & 12.76 & 12.96 \\
\hline Zygomatic width & 14 & & 14.80 & 14.15 & 14.37 \\
\hline Width of the braincase & 10.1 & 10.2 & 10.96 & 10.80 & 10.94 \\
\hline Width across the molars & 8 & 7.9 & - & 8.21 & 8.02 \\
\hline
\end{tabular}

which had ectoparasites, orange-brown pelage, with the venter paler than the dorsum, and dark hairs around the eyes (Fig. 1).

Sturnira tildae was also identified based on the following set of morphological cranial traits: small brain case and broad, high rostrum, slightly bilobed upper incisors with a wide base and narrower points, and first and second lower molars with lingual cusps separated by shallow grooves with no vertical border (Fig. 2A-D and Table 1).

The present study provides the first record of S. tildae from the Brazilian state of Maranhão, and only the fifth for the Brazilian Northeast geographic region (two from Bahia state - Faria \& Baumgarten, 2007; Faria, 2006, one from Pernambuco; Martins et al., 2020 and one from Ceará - Novaes \& Laurindo, 2014). The geographically closest locality to Cândido Mendes with records of S. tildae is Santa Barbara, in the neighboring state of Pará, which is ca. $280 \mathrm{~km}$ due west (Fonseca, 2006). There is also a record from the municipality of Muaná, in Pará (Marques-Aguiar et al., 2002), which is $402 \mathrm{~km}$ west of Cândido Mendes. Both these localities are within the Amazon biome. South of Maranhão, the nearest locality is in the municipality of Goiatins, in Tocantins state (Maas et al., 2018), which is $724 \mathrm{~km}$ to the south, in the Cerrado savanna biome, while the nearest record to the east is from the municipality of Barbalha, in Ceará state,

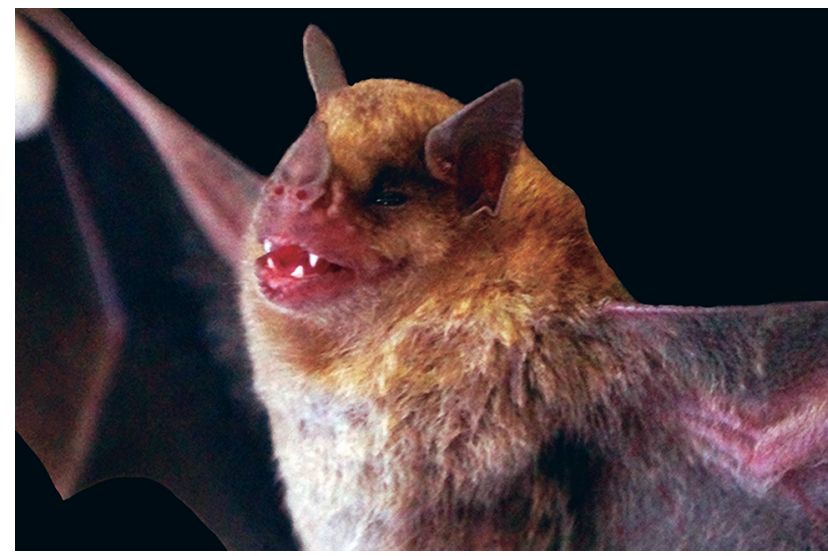

Figure 1. Sturnira tildae (female, RRM 117) collected em Cândido Mendes, in the Amazon biome of Maranhão state, Brazil. at a distance of $967 \mathrm{~km}$, in the Caatinga biome (Novaes \& Laurindo, 2014) (Fig. 3). The present study extends the known distribution of $S$. tildae to the eastern extreme of the Amazon biome.

The sequence of the rRNA $16 \mathrm{~S}$ gene obtained from the specimen analyzed in the present study diverged by $0.4 \%$ from those of S. tildae from French Guiana and by $4.8 \%$ from $S$. lilium. The BLAST search identified a genetic similarity of $100 \%$ with S. tildae from French Guiana. In the case of the COI gene sequences, intraspecific genetic divergence between the study specimen and sequences from French Guiana, Surinam, Ecuador, and Guyana was $0.92-1.58 \%$, while it was $11.8 \%$ in relation to S. lilium. In the BOLD Systems platform, the sequence returned a similarity of $99.09 \%$ with S. tildae from French Guiana (Table 2). These results are consistent with the morphological and craniometric identification of the specimen, and confirm the occurrence of S. tildae in the Amazon biome of Maranhão state.

\section{DISCUSSION}

In the present study, the cranial and morphological measurements of the specimen, are typical of S. tildae, as defined by De La Torre (1959), Simmons \& Voss (1998), Miretzki et al. (2002), López-Baucells et al. (2016), Velazco \& Patterson (2019), and Martins et al. (2020). The cranial and dental measurements of the specimen (skull, basal, and condylobasal lengths, the length of the upper tooth row, and the postorbital and zygomatic widths, the width of the braincase, and the width across the molars) are all very similar to those of the $S$. tildae specimens collected in Recife, Pernambuco (Martins et al., 2020) and Morretes, Paraná (Miretzki et al., 2002). This indicates that differences due to the geographic or sexual variation are negligible.

The species S. tildae has great morphological similarities with $S$. lilium, making identification difficult. (Simmons \& Voss, 1998). A number of diagnostic traits can nevertheless be used to distinguished the two taxa, including the length of the forearm, which exceeds $45 \mathrm{~mm}$ in S. tildae, but never exceeds this value in S. lilium (Simmons \& Voss, 1998; Reis et al., 2013, 2017; Martins 


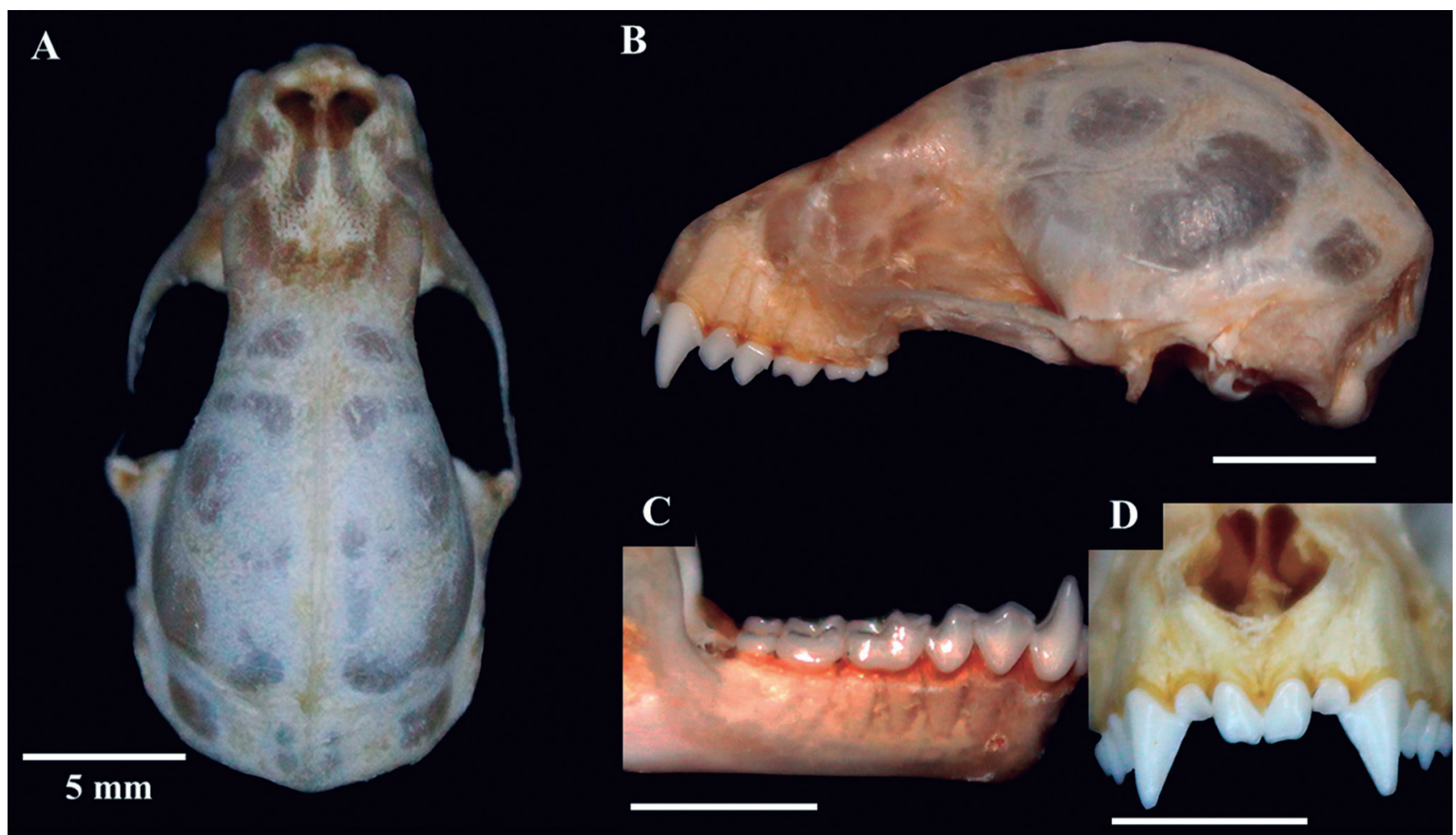

Figure 2. Skull of Sturnira tildae (RRM 117). (A) dorsal view showing the small braincase; (B) lateral view showing the broad, elongated rostrum; (C) lateral view of the mandible showing the first and second molars with lingual cusps separated by shallow grooves; (D) frontal view of the upper incisors, showing the slightly bilobed internal incisors with a wide base. Scale bar: $5 \mathrm{~mm}$. Source: Olímpio, A.P.M.; Lima, A.C.S.

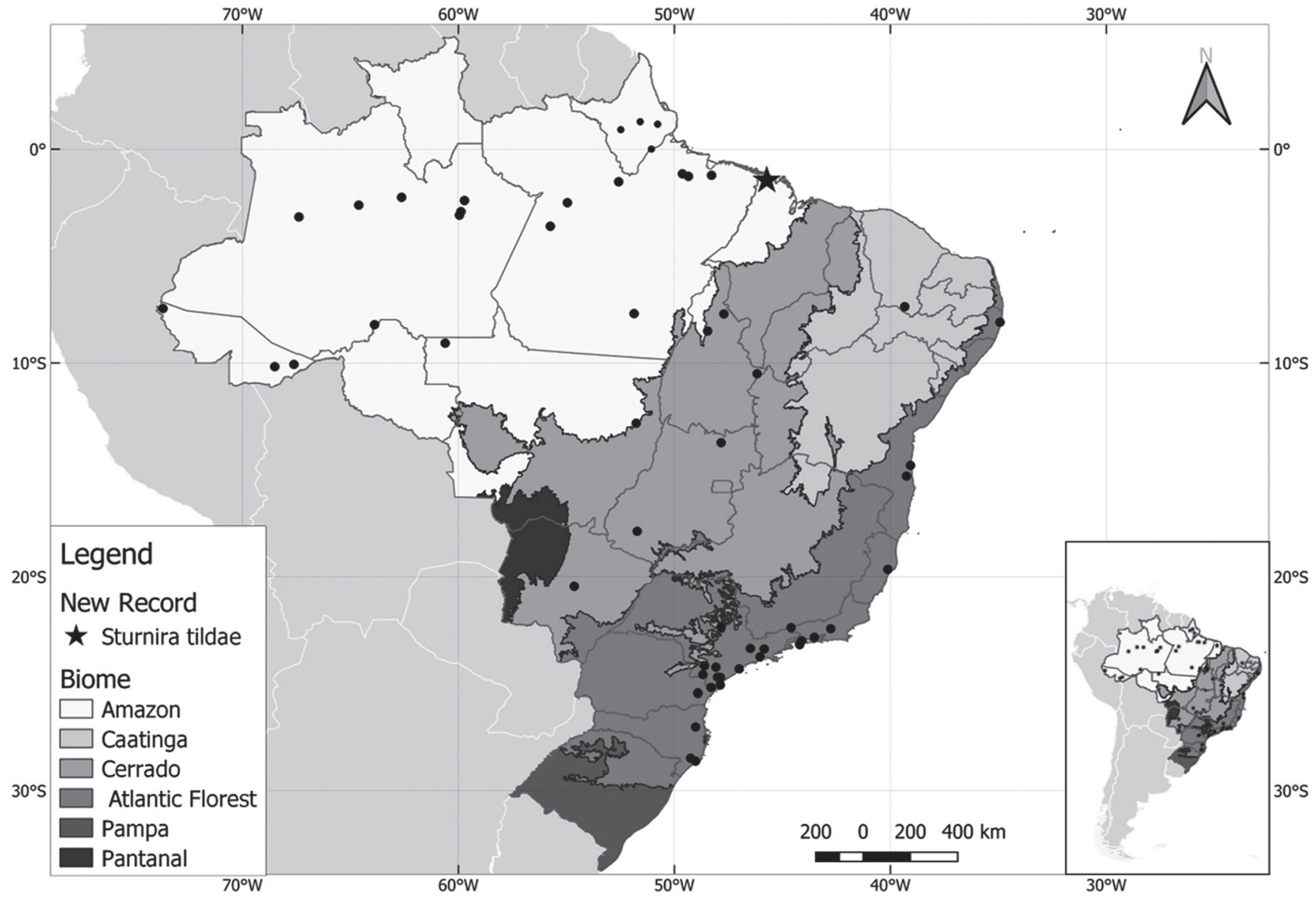

Figure 3. Geographic distribution of Sturnira tildae in Brazil. The locality reported in the present study in the state of Maranhão is shown by a star. The Brazilian biomes are shaded in black (Pantanal), darker to lighter gray (Pampas, Atlantic Forest, Cerrado, and Caatinga, in this order), and white (Amazon). Source: adapted from Martins et al. (2020). 
Table 2. Interspecific genetic divergence in Sturnira tildae based on the sequences of the COI gene, using the 2-parameter Kimura algorithm. Lophostoma silvicola and Carollia perspicillata were included as outgroups. Legend: $\mathrm{GUY}=$ Guyana, SUR $=$ Suriname, ECU = Ecuador, FGU = French Guiana, $C M=C$ andido Mendes, $C X=$ Caxias (Maranhão).

\begin{tabular}{|c|c|c|c|c|c|c|c|c|c|c|c|c|}
\hline \multirow{2}{*}{ Species/specimens } & \multicolumn{12}{|c|}{ Genetic Divergence (\%) } \\
\hline & 1 & 2 & 3 & 4 & 5 & 6 & 7 & 8 & 9 & 10 & 11 & 12 \\
\hline 1. S. tildae JF455913 GUY & - & & & & & & & & & & & \\
\hline 2. S. tildae JF455917 GUY & 0.17 & & & & & & & & & & & \\
\hline 3. S. tildae JQ601103 SUR & 0.34 & 0.52 & & & & & & & & & & \\
\hline 4. S. tildae JF447740 SUR & 0.52 & 0.69 & 0.52 & & & & & & & & & \\
\hline 5. S. tildae JF449229 ECU & 0.52 & 0.69 & 0.87 & 0.69 & & & & & & & & \\
\hline 6. S. tildae JF449230 ECU & 0.34 & 0.52 & 0.69 & 0.52 & 0.17 & & & & & & & \\
\hline 7. S. tildae KU295485 GUF & 0.00 & 0.18 & 0.36 & 0.55 & 0.55 & 0.36 & & & & & & \\
\hline 8. S. tildae HG003314 GUF & 0.17 & 0.34 & 0.52 & 0.69 & 0.69 & 0.52 & 0.18 & & & & & \\
\hline 9. S. tildae RRM117 CM & 1.04 & 1.22 & 1.40 & 1.58 & 1.58 & 1.40 & 0.92 & 1.22 & & & & \\
\hline 10. S. Iilium CESC52 CX & 11.5 & 11.6 & 11.5 & 11.7 & 12.2 & 11.5 & 12.2 & 12.2 & 11.8 & & & \\
\hline 11. L. silvicola CESC51CX & 23.5 & 23.8 & 23.5 & 22.8 & 23.1 & 23.5 & 23.8 & 23.8 & 24.4 & 22.7 & & \\
\hline 12. C. perspicillata CESC $9 \mathrm{CX}$ & 27.0 & 26.6 & 27.4 & 27.4 & 26.3 & 26.6 & 28.2 & 27.4 & 27.6 & 24.5 & 24.7 & - \\
\hline
\end{tabular}

et al., 2020); the lighter coloration of the pelage of the venter in S. tildae in comparison with S. lilium, and the larger lengths of the ear, tibia, wing, and condylobasal length in S. tildae (Fazzolari-Correa, 1995; Davis, 1980). All these differences were also observed in the $S$. tildae specimen analyzed in the present study.

The dentition provides the most reliable evidence for the differentiation of the two species, given the presence of bilobed internal superior incisives and wider in $S$. tildae, than observed in S. lilium (Eisenberg, 1989), as well as the lingual cusps of the first and second molars of the mandible, S. lilium has high lingual cusps, separated by a deep vertical notch between the first and second molars and in S. tildae these cusps are low and separated by shallow notches (Miretzki et al., 2002). These authors considered the differences in the configuration of the cusps of the mandibular molars to be completely reliable for the distinction of the specimens of S. lilium and S. tildae from Paracou, in French Guiana, and this conclusion was further confirmed in the present study.

The analyses of the 16S rRNA and COI genes revealed a high degree of similarity, in both cases, between the specimen presented here and $S$. tildae from French Guiana, with a genetic divergence of less than $2 \%$ in comparison with the specimens from of different localities, which is consistent with the $2 \%$ intraspecific threshold of the COI marker established for bats by Clare et al. (2011). Despite the fact that S. lilium and S. tildae present major morphological similarities, the analysis of the rRNA $16 \mathrm{~S}$ sequences indicated a divergence of $4.8 \%$ between the S. tildae specimen presented here and S. Iilium, increasing to $11.8 \%$ for the COI gene. The genetic data thus support conclusively the morphological and craniometric analyses, and confirm the occurrence of S. tildae in Maranhão.

As for distribution, S. tildae is considered a common species within its geographic distribution (Wilson 1996; Miretzki et al., 2002), with a distinct preference for more humid forest environments (Trajano, 1984; Marques, 1985; Brosset et al., 1996; Simmons \& Voss, 1998; Miretzki et al., 2002; Novaes \& Laurindo, 2014), such as the locality surveyed during the present study. Even so, S. tildae has been captured relatively infrequently in most bat field studies, in all different biomes (Oliveira, 2000; MarquesAguiar et al., 2002; Miretzki et al., 2002; Carvalho et al., 2013; Luz et al., 2013; Menezes et al., 2015; Maas et al., 2018; Cláudio et al., 2020; Martins et al., 2020).

In Brazil, S. tildae has been recorded in the Amazon, Atlantic Forest, Cerrado, and Caatinga biomes. In the Amazon biome (IBGE, 2019), there are records from the Brazilian states of Amazonas, Acre, Rondônia, Pará, Amapá, Roraima, and Mato Grosso (Tavares et al., 2008; Reis et al., 2013; Novaes \& Laurindo, 2014; Reis et al., 2017), and the closest locality to the present study site is $280 \mathrm{~km}$ west, in Pará. This is the fifth record of the occurrence of $S$. tildae in the Brazilian Northeast. The previous records included one from the Caatinga biome, in Barbalha, Ceará state (Novaes \& Laurindo, 2014), and three from the Atlantic Forest, in Ilhéus (Faria \& Baumgarten, 2007) and Una (Faria, 2006), both in Bahia, and Recife in Pernambuco state (Martins et al., 2020). Barbalha is very close - about $20 \mathrm{~km}$ - to Floresta Nacional do Araripe. The area is considered to be a relict of Atlantic Forest in the middle of the Caatinga (Silveira et al., 2019).

\section{CONCLUSIONS}

The present study recorded the occurrence of S. tildae in the Amazon biome of the Brazilian state of Maranhão, based on both morphological and molecular evidence. This is the first record of the species for the state, and the fifth for the Brazilian Northeast, and extends the known distribution of the species to the municipality of Cândido Mendes, $280 \mathrm{~km}$ east of the nearest locality in the Amazon biome. The findings of the study reinforce the need for attention when identifying the species of the genus Sturnira, in particular in areas where S. lilium and S. tildae are likely to be captured together and then released, given that the considerable morphological similarities of these sympatric taxa may result in errors of identification. As S. tildae occurs more frequently in moist 
forests, new records are expected in other Amazonian areas in Maranhão, as well as in Brejos de Altitude habitats within the Caatinga biome (see Tabarelli \& Santos, 2004).

\section{ACKNOWLEDGMENTS}

ACSL and FHSC were supported by postgraduate fellowships and BATPC was supported by Coordenação de Aperfeiçoamento de Pessoal de Nível Superior (CAPES) postdoctoral fellowships. CLSC was supported by a postgraduate grant from the Universidade Estadual do Maranhão (UEMA). This study was financed in part by CAPES - Financial Code 001 and the Foundation for Research and Scientific and Technological Development of Maranhão (FAPEMA).

\section{AUTHORS' CONTRIBUTIONS}

ACSL: Conceptualization, Writing - original draft, Visualization, Investigation, Data curation, Formal Analysis, Validation. CLSC: Conceptualization, Visualization, Writing - review \& editing. SBM: Visualization, Methodology, Data curation, Writing - review \& editing. FHSC: Visualization, Methodology, Writing - review \& editing. BATPC: Supervision, Data curation, Writing - review \& editing. ECF: Supervision, Writing - review \& editing, Funding acquisition, Project administration, Validation. MCB: Supervision, Writing - review \& editing, Formal Analysis, Validation, Data curation, Funding acquisition, Project administration. All the authors actively participated in the discussion of the results, they reviewed and approved the final version of the paper.

\section{CONFLICT OF INTEREST}

Authors declare that there is no conflict of interest.

\section{REFERENCES}

Bandeira, I.C.N. 2013. Geodiversidade do estado do Maranhão. Programa Geologia do Brasil. Levantamento da Geodiversidade. Teresina, CPRM. 294p.

Bernard, E.; Tavares, V.C. \& Sampaio, E. 2011. Compilação atualizada das espécies de morcegos (Chiroptera) para a Amazônia Brasileira. Biota Neotropica, 11(1): 35-46. D0I

Brosset, A.; Charles-0ominique, P.; Cockle, A.; Cosson, J.F. \& Masson, 0. 1996. Bat communities and dcforestation in French Guiana. Canadian Journal of Zoology, 74(11): 1974-1982. D0I

Brunet, A.K. \& Austad, S.N. 2004. Aging studies on bats: a review. Biogerontology, 5(4): 211-222. DOI

Carvalho, F.; Fabián, M.E. \& Menegheti, J.0. 2013. Vertical structure of an assemblage of bats (Mammalia: Chiroptera) in a fragment of Atlantic Forest in Southern Brazil. Zoologia, 30(5): 491-498. DOI

Clare, E.L.; Lim, B.K.; Fenton, M.B. \& Hebert, P.D.N. 2011. Neotropical bats: estimating species diversity with DNA barcodes. PLOS ONE, 6(7): 322-648. D01
Cláudio, V.C.; Barbosa, G.P.; Rocha, V.J.; Moratelli, R. \& Rassy, F.B. 2020. The bat fauna (Mammalia: Chiroptera) of Carlos Botelho State Park, Atlantic Forest of Southeastern Brazil, including new distribution records for the state of São Paulo. Zoologia, 37(e36514): 1-32. D0l

Davis, W.B. 1980. New Sturnira (Chiroptera, Phylostomidae) from Central and South America, with key to currently recognized species. Occasional Papers of the Museum of Texas Tech University, 93: 1-16. D0I

De La Torre, L. 1959. A new species of bat of the genus Sturnira (Phyllostomidae) from the Island of Trinidad, West Indies. Natural History Miscellanea, Chicago, 166: 1-6.

Eisenberg, J.F. 1989. Mammals of the Neotropics: the northern Neotropics. Chicago, The University of Chicago Press. v. 1, 449p.

Faria, D. 2006. Phyllostomid bats of a fragmented landscape in the northeastern Atlantic forest, Brazil. Journal of Tropical Ecology, 22(5): 531-542. D0I

Faria, D. \& Baumgarten, J. 2007. Shade cacao plantations (Theobroma cacao) and bat conservation in southern Bahia, Brazil. Biodiversity and Conservation, 16(2): 291-312. DOI

Fazzolari-Correa, S. 1995. Aspectos sistemáticos, ecológicos e reprodutivos de morcegos na Mata Atlântica. Doctoral thesis. São Paulo, Universidade de São Paulo, Instituto de Biociências. 168p.

Fleming, T.H.; Dávalos, L.M. \& Mello, M.A.R. 2020. Phyllostomid bats: a unique mammalian radiation. Chicago, The University of Chicago Press. 489p.

Folmer, 0.; Black, M.; Hoeh, W.; Lutz, R. \& Vrijenhoek, R. 1994. DNA primers for amplification of mitochondrial Cytochrome C Oxidase Subunit 1 from diverse metazoan invertebrates. Molecular Marine Biology and Biotechnology, 3(5): 294-299.

Fonseca, R.T.D. 2006. Diversidade da quiropterofauna (Mammalia) no Parque Ecológico de Gunma, Santa Bárbara do Pará. Master thesis. Belém, Universidade Federal do Pará. 120p.

Garbino, G.S.T.; Gregorin, R.; Lima, I.P.; Loureiro, L.; Moras, L.M.; Moratelli, R.; Nogueira, M.R.; Pavan, A.C.; Tavares \& Peracchi, V.C. 2020. Updated checklist of Brazilian bats: versão 2020. Comitê da Lista de Morcegos do Brasil - CLMB. Sociedade Brasileira para o Estudo de Quirópteros (SBEQ). Available: https://www.sbeq.net/lista-de-especies. Access: 01/05/2021.

Gardner, A.L. 2008. Tribe Sturnirini. In: Gardner, A.L. (Ed.). Mammals of South America. Volume 1: Marsupials, Xenarthrans, Shrews, and Bats. Chicago, The University of Chicago Press. p. 363-376.

Hall, T.A. 1999. BioEdit: a user-friendly biological sequence alignment editor and analysis program for Windows 95/98/NT. Nucleic acids symposium, 41: 95-98.

Instituto Brasileiro de Geografia e Estatística (IBGE). 2019. Biomas e sistema costeiro-marinho do Brasil: compatível com a escala 1:250.000. Rio de Janeiro. Coordenação de Recursos Naturais e Estudos Ambientais, Relatórios metodológicos (IBGE), ISSN 0101-2843, 164pp.

Kumar, S.; Stecher, G.; Lim, Knyaz \& Tamura, K. 2018. MEGA X: Molecular Evolutionary Genetics Analysis across computing platforms. Molecular Biology and Evolution, 35(6): 1547-1549.

Lima, A.C.S.; Cardoso, F.H.S.; Mendes, S.B.; Fraga, E.C. \& Barros, M.C. 2018. New records of Niceforo's big-eared bat, Trinycteris nicefori (Sanborn, 1949) (Chiroptera, Phyllostomidae), from the state of Maranhão, Brazil. ZooKeys, 787: 127-134. D0I

López-Baucells, A.; Rocha, R.; Bobrowiec, P.E.D.; Palmeirim, J.M. \& Meyer, C.F.J. 2016. Field guide to amazonian bats. Manaus, Editora INPA. 173p.

Luz, J.L.; Costa, L.M.; Jordão-Nogueira, T.; Esbérard, C.E.L. \& Bergallo, H.G. 2013. Morcegos em área de Floresta Montana, Visconde de Mauá, Resende, Rio de Janeiro. Biota Neotropica, 13(2): 190-195. DOI

Maas, A.C.S.; Gomes, L.; Martins, M.A.; Dias, D.; Pol, A.; Chaves, G.F.; Schutte, M.; Araújo, R. \& Peracchi, A.L. 2018. Bats in a Cerrado landscape of Northern Brazil: species occurrence, influence of environmental 
heterogeneity and seasonality, and eight new records for the state of Tocantins. Mammalia, 82(5): 469-480. DOI

Marques, S.A. 1985. Novos registros de morcegos do Parque Nacional da Amazônia (Tapajós), com observações do período de atividade noturna e reprodução. Boletim do Museu Paraense Emílio Goeldi Zoologia, 2(1): 71-83. Available: https://repositorio.museu-goeldi.br/handle/ mgoeldi/401.

Marques-Aguiar, S.A.; Melo, C.C.S.; Aguiar, G.F.S. \& Queiroz, J.A.L. 2002. Levantamento preliminar da mastofauna da região de Anajás-Muaná, Ilha de Marajó, Pará, Brasil. Revista Brasileira de Zoologia, 19(3): 841-854. D0I

Martins, T.C.S.L.; Leal, E.S.B.; Neves, C.H.C.B.; Ferreira, A.F.; Silva, L.G.; Garcia, A.C.L. \& Montes, M.A. 2020. First record of Sturnira tildae De La Torre, 1859 (Chiroptera, Phyllostomidae) for the state of Pernambuco, Brazil. Oecologia Australis, 24(1): 223-234. D0I

Mendes, S.B.; Lima, A.C.S.; Reis, T.S.; Fraga, E.C. \& Barros, M.C. 2020. First record of Cynomops planirostris (Peters, 1865) (Chiroptera, Molossidae) from Maranhão state, Brazil, based on morphological and molecular data. Brazilian Journal of Biology, 80(2): 405-409. D0I

Menezes, L.F.; Pinto, A.C.D.C.; Contildes, M.D.R. \& Peracchi, A.L. 2015. Lista de morcegos (Mammalia Chiroptera) do Parque Natural Municipal da Serra do Mendanha, Município do Rio de Janeiro, RJ, Brasil. In: Pontes, J.A.L. (Ed.). Biodiversidade carioca. Rio de Janeiro, Technical Books. p. 238-245.

Miretzki, M.; Perrachi, A.L. \& Bianconi, G.V. 2002. Southernmost records of Sturnira tildae De La Torre, 1959 (Chiroptera: Phyllostomidae) in Brazil. Mammalia, 66(2): 306-309.

Novaes, R.L.M. \& Laurindo, R.S. 2014. Morcegos da Chapada do Araripe, Nordeste do Brasil. Papéis Avulsos de Zoologia, 54(22): 1-13. D01

Olímpio, A.P.M.; Cardoso, F.H.S.; Costa, C.L.S.; Fraga, E.C. \& Barros, M.C. 2018. Expansion of the known range of the lesser bulldog bat, Noctilio albiventris Desmarest, 1818 (Chiroptera, Noctilionidae) in the Brazilian Cerrado. Check List, 14(2): 313-317. D0I

Olímpio, A.P.M.; Ventura, M.C.S.; Mascarenhas, M.J.0.; Nascimento, D.C.; Andrade, F.A.G.; Fraga, E.C. \& Barros, M.C. 2016. Bat fauna of the Cerrado savanna of eastern Maranhão, Brazil, with new species occurrences. Biota Neotropica, 16(3), e20150089. DOI

Oliveira, E.R. 2000. Espaço ecomorfológico da fauna de quirópteros da região do Alto Tocantins, G0: uma perspectiva através da análise da morfologia alar. Master thesis. Rio de Janeiro, Universidade Federal do Rio de Janeiro. 82p.

Oliveira, T.G.; Júnior, J.S.S. \& Dias, P.A. 2011. Mamíferos da Amazônia maranhense. In: Martins, M.B. \& Oliveira, T.G. (Eds.). Amazônia Maranhense: Diversidade e conservação. Belém, Museu Paraense Emílio Goeldi. p. 251-267.

Pacheco, S.M. 2004. Técnicas de campo empregadas no estudo de quirópteros. Caderno La Salle XI, Canoa, 1(2): 195-202.

Palumbi, S.; Martin, A.; Romano, S.; McMillan, W.0.; Stice, L.; Grabowski, G. \& MacMillan, W.0. 2002. The simple fool's guide to $P C R$, version 2.0. University of Hawaii, Honolulu.

Peracchi, A.L.; Lima, I.P.; Reis, N.R.; Nogueira, M.R. \& Filho, H.0. 2011. Ordem Chiroptera. In: Reis, N.R.; Peracchi, A.L.; Pedro, W.A. \& Lima, I.P.Mamíferos do Brasil. 2. ed. Londrina. p. 155-234.
Reis, N.R.; Fregonezi, M.N.; Peracchi, A.L. \& Shibatta, A.0. 2013. Morcegos do Brasil: guia de campo. Rio de Janeiro, Technical Books. 225p.

Reis, N.R.; Peracchi, A.L.; Batista, C.B.; Lima, I.P. \& Pereira, A.D. 2017. História natural dos morcegos brasileiros: chave de identificação de espécies. Rio de Janeiro, Technical Books. 416p.

Sampaio, E.; Lim, B. \& Peters, S, 2016. Sturnira tildae. The IUCN Red List of Threatened Species 2016: e.T20960A22050501. D0I

Sanger, F.; Nichlen, S. \& Coulson, A.R. 1977. DNA sequencing with chain termination inhibitors. Proceedings of the National Academy of Sciences Cambridge, 74(12): 5463-5467.

Silveira, M.H.B.; Mascarenhas, R.; Cardoso, D. \& Batalha-Filho, H. 2019. Pleistocene climatic instability drove the historical distribution of forest islands in the northeastern Brazilian Atlantic Forest. Palaeogeography, Paleoclimatology, Palaeoecology, 527: 67-76.

Simmons, N.B. 2005. Order Chiroptera. In: Wilson, D.E. \& Reeder, D.M. (Eds.). Mammals species of the world: a taxonomic a geographic reference. 3. ed. Baltimore, Johns Hopkins University Press. v. 1, p. 312-529.

Simmons, N.B. \& Voss, R.S. 1998. The mammals of Paracou, French Guiana: a neotropical lowland rainforest fauna. Part I. Bats. Bulletin of the American Museum of Natural History, 237: 1-219.

Tabarelli, M. \& Santos, A.M.M. 2004. Uma Breve Descrição Sobre a História Natural dos Brejos Nordestinos. In: Pôrto, K.C.; Cabral, J.J.P. \& Tabarelli, M. (Eds.). Brejos de Altitude em Pernambuco e Paraíba - História Natural, Ecologia e Conservação. 17-24pp.

Tavares, V.C.; Gregorin, R. \& Peracchi, A.L. 2008. Diversidade de morcegos no Brasil: lista atualizada com comentários sobre distribuição e taxonomia. In: Pacheco, S.M.; Marques, R.V. \& Esberard, C.E.L. (Eds.). Morcegos no Brasil: Biologia, Sistemática, Ecologia e Conservação. Armazém Digital Comunicação Ltda., Porto Alegre, 25-58.

Taylor, M. \& Tuttle, M.D. 2019. BATS: an illustrated guide to all species. (4a ed.), China: science editor \& photographer, 403pp.

Trajano, E. 1994. Ecologia de populações de morcegos cavernícolas em uma região cárstica do sudeste do brasil. Revista Brasileira de Zoologia, 2(5): 255-320. DOI

Velazco, P. \& Patterson, B.D. 2017. Sturnira lilium. The IUCN Red List of Threatened Species 2017: e.T88159688A22049384. D01

Velazco, P.M. \& Patterson, B.D. 2019. Small mammals of the Mayo river basin in northern Peru, with the description of a new species of Sturnira (Chiroptera: Phyllostomidae). Bulletin of the American Museum of Natural History, 429: 1-67.

Velazco, P.M. 2021. Murciélagos del Perú/Bats of Peru. Available: http://www. paulvelazco.com/murcielagos peru.html. Access: 10/07/2021.

Vizzoto, L.D. \& Taddei, V.A. 1973. Chave para determinação de quirópteros brasileiros. Revista da Faculdade de Filosofia, Ciências e Letras. Boletim de Ciências, São José do Rio Preto, 1: 1-72.

Wilson, D.E. 1996. Neotropical bats: a checklist with conservatian status. In: Gibson, A.C.; Mildred, E. \& Mathias, B.G. Neotropical Biodiversity and Conservation, University of Califonia, Los Angeles, Califonia, pp. 167-177. 